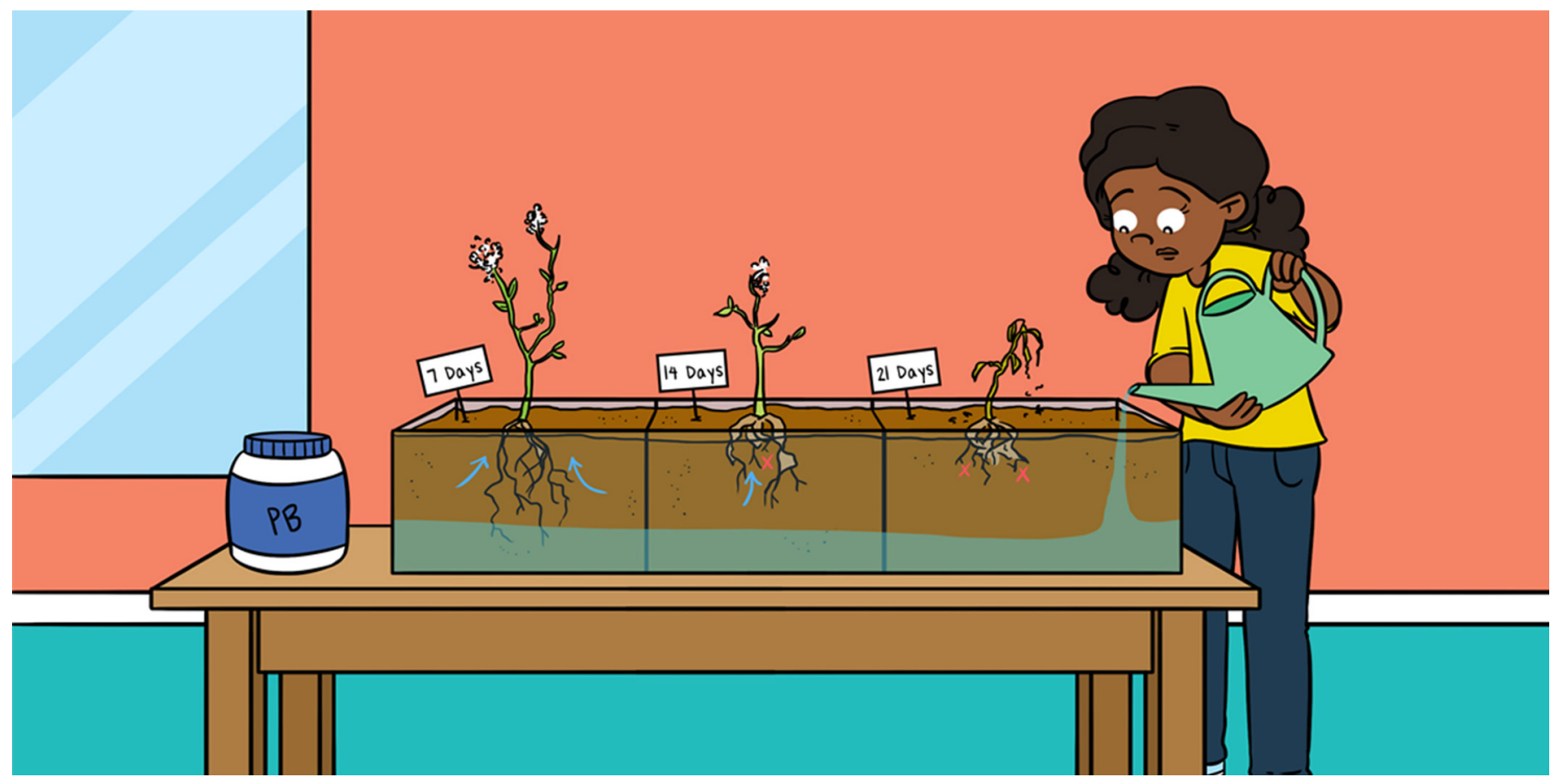

\title{
FROM THE SOIL TO THE CLUB IN THE ROOTS: CLUBROOT
}

\section{Edel Pérez-López *}

Département de Phytologie, Faculté des Sciences de l'Agriculture et de l'Alimentation, Centre de Recherche et d'Innovation des Végétaux, Université Laval, Québec City, QC, Canada

YOUNG REVIEWER:

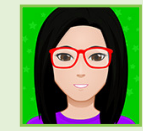

JUNIPER

AGE: 11
Among the millions of microorganisms inhabiting the soils, some can be plant pathogens, meaning they can become a disease to plants. Some diseases are more well-known than others. This is the case of clubroot, a very atypical microorganism that infects cruciferous plants, such as cabbage, kale, canola, and the common research plant thale cress. In this article, I will tell you more about clubroot and clubroot disease because there is still a lot to discover about the pathogen and the disease. Maybe you will be part of our lab in the future and investigate a fascinating soil-borne pathogen.

\section{A TALE OF PROTISTS AND PLANTS}

Soils are alive. Insects, worms, and microorganisms live in the soil and many of them live in close interaction with plants. Those interactions are not always beneficial for the plants. The soil also harbors creatures that represent a risk for ecologically and economically important plants. Some fungi and worms are 
Figure 1

Two important plant hosts susceptible to clubroot: thale cress and rapeseed. Figure created with BioRender.

\section{SOIL-BORNE}

\section{PATHOGEN}

Microorganisms that survive and move about in the soil and can make plants ill.

\section{PROTISTS}

Tiny, one-celled organisms that are not animals, plants, or fungi.

\section{CRUCIFEROUS}

\section{VEGETABLES}

Vegetables of the family Brassicaceae, including many green leafy vegetables like cauliflower, cabbage, kale, garden cress, bok choy, broccoli, and Brussels sprouts.

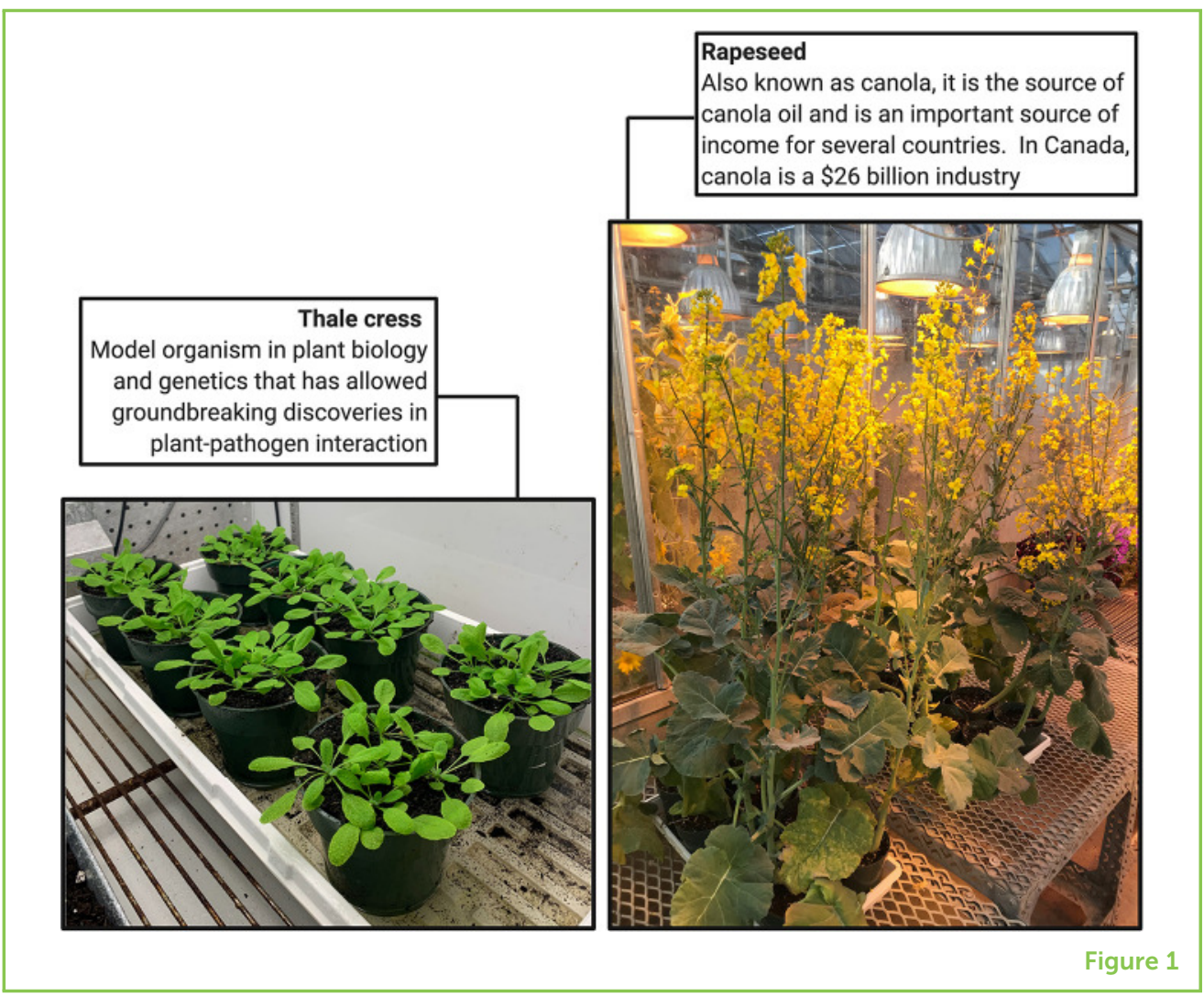

well-known soil-borne pathogens for plants, but they are not the only ones. Some protists are also devastating soil-borne plant pathogens, although they are less studied and known. Protists are one-celled organisms that are not animals, plants, or fungi.

The clubroot pathogen, or Plasmodiophora brassicae like scientist call it, is a protist that affects the roots of cruciferous vegetables, such as broccoli, cabbage, cauliflower, the oilseed plant known as canola, and thale cress that is commonly used in plant research [1]. Thale cress and canola are one important host for clubroot, but for different reasons (Figure 1). Thale cress is a very useful plant for scientists that study various aspects of plants, such as their genomes, ecology, and relationships with beneficial microorganisms or pathogens [2]. Thale cress plants infected by clubroot are the perfect model to study how the pathogen affects the plant. Another plant that is extremely important from an economic point of view is canola (Figure 1). Canola is the source of canola oil, a product used in many kitchens around the world. In Canada alone, canola represents around \$26 billion dollars (CAD) for the Canadian economy, so a pathogen that puts canola production at risk could be devastating for the economy [1]. 
Figure 2

Lifecycle of clubroot and establishment of clubroot disease. (A) Clubroot can exist for years as a resting spore in the soil. When the spore contacts a susceptible plant, turns into zoospore and, infects the roots and forms galls. The infected roots eventually release more spores into the soil, which can go on to infect new plants. (B) Healthy plant vs. a clubroot infected plant (A) Based on Auer and Ludwig-Müller [3] and created with BioRender.

\section{SPORE}

Structure created by clubroot that has a thick cell wall to help it survive for many years in the soil when it is not able to infect a plant.

\section{GALLS}

Abnormal swelling or outgrowth of plant tissues caused by microbial plant pathogens or insects.

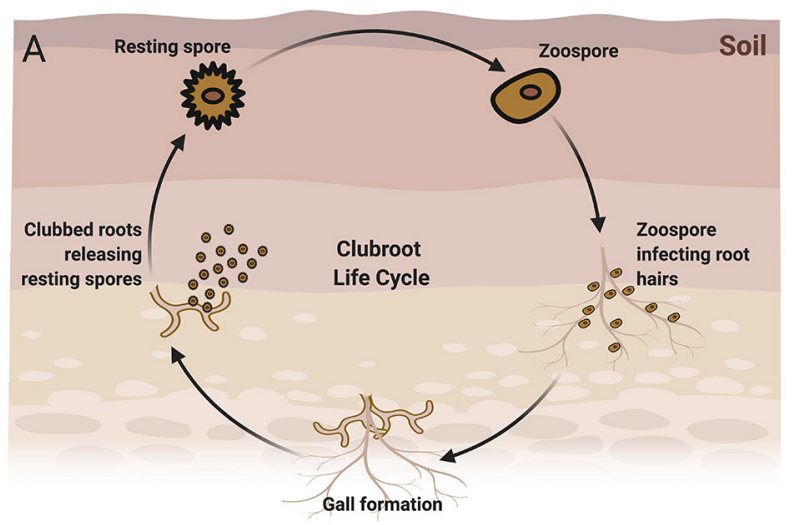

B
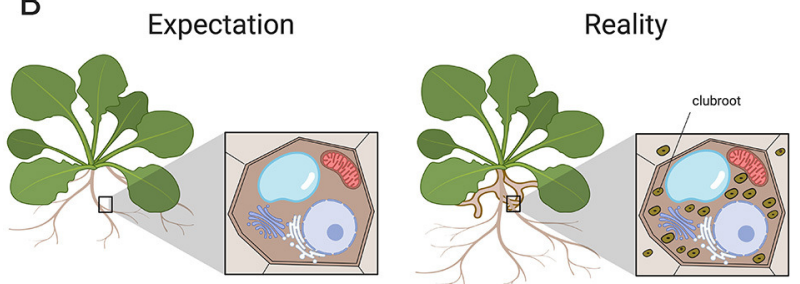

Figure 2

\section{THE LIFE CYCLE OF CLUBROOT}

The clubroot pathogen can live in the soil for up to 20 years as an inactive spore. Spores are structures created by some plant pathogens that are released to the environment and have a thick cell wall to help it survive for many years in the soil when are not able to infect a plant. If a susceptible plant grows in soil containing clubroot spores, then the resting spores "wake up" turning now in zoospores and attach to the roots of the plant and start an infection. The infection process is divided into two phases: primary infection and secondary infection (Figure 2A). During primary infection, the clubroot pathogen encounter the roots and penetrate, starting the infection. Although primary infection is important, it is during secondary infection that clubroot induces galls, also called clubs, in the roots of susceptible plants. Galls are abnormal swelling of plant tissue induced by plant pathogens or insects. The galls prevent the plant from absorbing water and nutrients from the soil and eventually cause the plants to die. The clubroot life cycle concludes with the production of new resting spores, which are released back to the soil, ready to infect a new plant.

\section{CLUBROOT OR A CLUB IN THE ROOTS?}

The clubs are the reason why this disease is known as clubroot. When I heard of clubroot for the first time, I thought it meant "a club in the roots." However, as fun as it sounds, that expectation is quite different from reality (Figure 2B). If anyone is having fun in the infected root, it is definitely not the plant! The reality is that the clubs induced by 


\section{Figure 3}

Canola (A), broccoli (B), arugula (C), and kale $(D, E)$ roots affected by clubroot, and healthy canola roots (F).

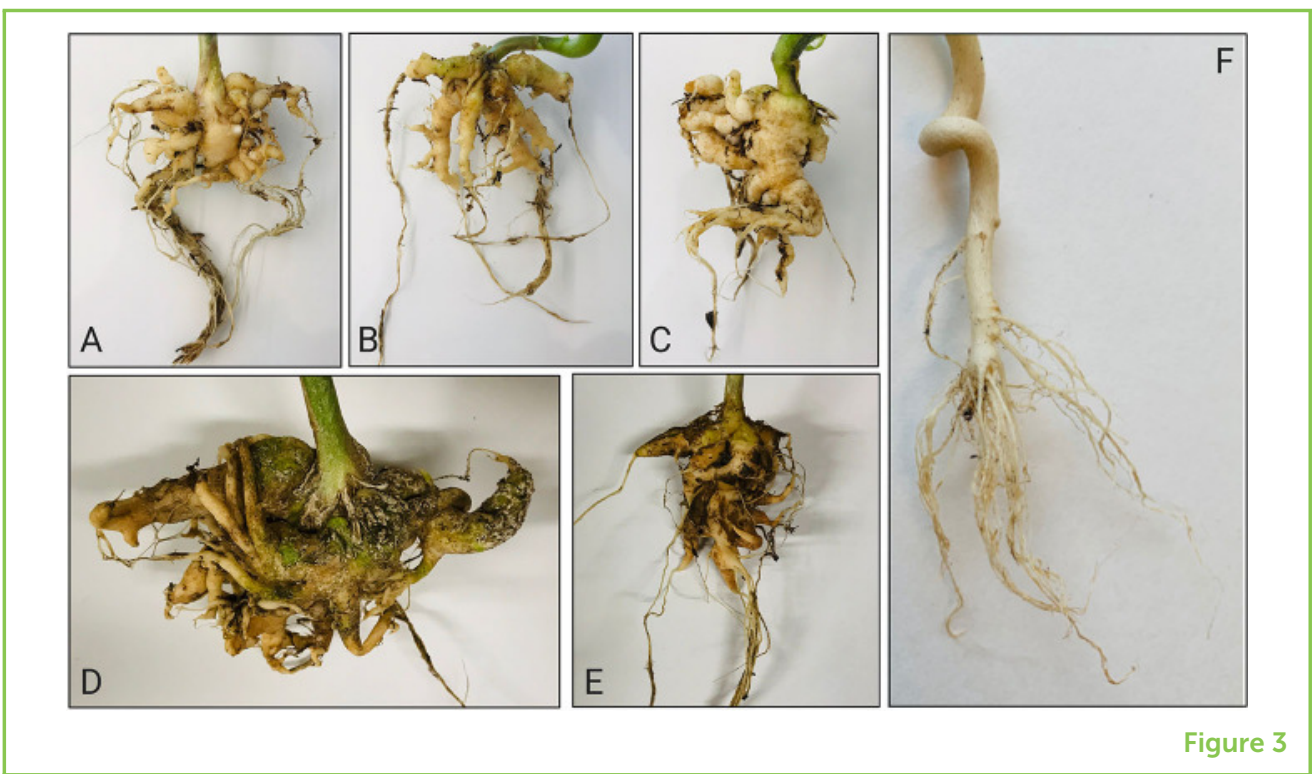

clubroot are devastating. In the laboratory, we found that 21 days after adding clubroot to the soil, susceptible plants start to die. The xylem and phloem, which are the channels used by plants to transport water and nutrients, are totally blocked. It is also interesting to note that the galls caused by clubroot are quite similar in different plant hosts (Figure 3).

\section{HOW CAN WE MANAGE CLUBROOT AND FIGHT CLUBROOT DISEASE?}

Although clubroot and the disease it causes were discovered back in the 1600s, there are a lot of things that scientists do not know [1]. To manage clubroot, farmers have been using chemicals, such as fungicides, with little success. Growing plants that are resistant to clubroot disease is the best strategy. However, after only a few years, clubroot develops new strategies to infect those resistant plants, making them susceptible to clubroot disease.

We are trying to fight an enemy that we do not understand very well, so the first step in the war against clubroot disease is to uncover all the tricks that this pathogen is hiding up its sleeves. In the University Laval (Quebec City, Canada), scientists are taking important steps toward understanding clubroot and the disease it causes. They want to know how clubroot escapes the plant immune system and how it can make the cells grow to form the galls. Their ultimate goal is to develop plants that are resistant to clubroot disease that can survive in a field with or without clubroot spores in it. Maybe in a few years you, the young curious mind reading this, will be part of the team tackling this intriguing pathogen. 


\section{REFERENCES}

1. Botero, A., García, C., Gossen, B. D., Strelkov, S. E., Toddd, C. D., Bonham-Smith, P. C., et al. 2019. Clubroot disease in Latin America: distribution and management strategies. Plant Pathol. 68:827-33. doi: 10.1111/ppa.13013

2. Krämer, U. 2015. Planting molecular functions in an ecological context with Arabidopsis thaliana. eLife 4:e06100. doi: 10.7554/eLife.06100

3. Auer, S., and Ludwig-Müller, J. 2015. Biological control of clubroot (Plasmodiophora brassicae) by the endophytic fungus Acremonium alternatum. J. Endocytobiosis Cell Res. 26:46-9. Available online at: https://zs.thulb.unijena.de/receive/jportal_jparticle_00346200

SUBMITTED: 16 May 2020; ACCEPTED: 20 May 2021; PUBLISHED ONLINE: 15 June 2021.

EDITED BY: Helen Phillips, Saint Mary's University, Canada

CITATION: Pérez-López E (2021) From the Soil to the Club in the Roots: Clubroot. Front. Young Minds 9:562915. doi: 10.3389/frym.2021.562915

CONFLICT OF INTEREST: The author declares that the research was conducted in the absence of any commercial or financial relationships that could be construed as a potential conflict of interest.

COPYRIGHT @ 2021 Pérez-López. This is an open-access article distributed under the terms of the Creative Commons Attribution License (CC BY). The use, distribution or reproduction in other forums is permitted, provided the original author(s) and the copyright owner(s) are credited and that the original publication in this journal is cited, in accordance with accepted academic practice. No use, distribution or reproduction is permitted which does not comply with these terms.

\section{YOUNG REVIEWER}

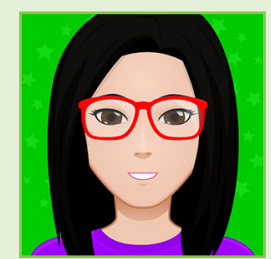

\section{JUNIPER, AGE: 11}

I like reading and coding. I also like animals. My favorite subjects in school are mathematics and art.

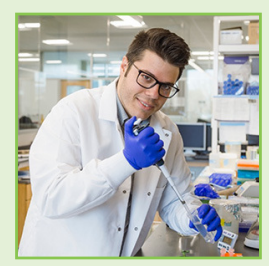

\section{AUTHOR}

\section{EDEL PÉREZ-LÓPEZ}

I am an Assistant Professor at the department of Plant Sciences at the University Laval, Quebec City, Canada. I am from a small agricultural town in Cuba and agriculture was always part of my life. That is why I decided to study biochemistry and to investigate the pathogens affecting plants and agriculture. In 2018, when I first learned about clubroot and clubroot disease, I felt in love with that intriguing pathogen, and it is now a central part of my research. I hope that someday one of you, a curious mind reading this, can be part of Edelab (https://edelabcriv.com/) to discover the mysteries behind pathogen-plant interactions. *edel.perez-lopez.1@ulaval.ca 